I Made Enra Kartika Yudha. Pemetaan Kemiskinan dan Otonomi Daerah di Provinsi Bali.....312

\title{
PEMETAAN KEMISKINAN DAN OTONOMI DAERAH DI PROVINSI BALI DENGAN MULTIDIMENSIONAL SCALING
}

\author{
I Made Endra Kartika Yudha
}

Fakultas Ekonomi Dan Bisnis Universitas Udayana, Bali, Indonesia Email: kartikayudha@unud.ac.id

\begin{abstract}
Poverty Mapping and Regional Autonomy in Bali Province with Multidimensional Scaling. Poverty and regional autonomy have become a hot issue in Indonesia. The problem of poverty has become one of the focuses in both the MDGs and SDGs. Regional autonomy has also become a major concern in the development of government management in Indonesia, given the development of regional autonomy encountered many challenges such as corruption with indicators in the form of regional heads affected by the problem of corruption. For this reason, it is important to mapping and it provides a good visual picture of regional autonomy and poverty. This research is conduct in Bali Province in 2018 using time series data. This study uses multidimensional scaling to map relationships between objects that have similarities. The findings in this study are that regional autonomy does not produce the same relationship with poverty in every region in Bali Province. For low poverty independent regions such as Badung Regency and Denpasar City, it is shown that regional autonomy with a high level of financial independence can produce a low number of poor people compared to other regions in the Province of Bali. There are also findings that there are areas of low poverty independent such as Klungkung, Bangli, and Jembarana districts. High regional financial capacity is not a reference in producing low poverty in an area.
\end{abstract}

Keywords: Poverty; Decentralization; $M D S$.

\begin{abstract}
Abstrak: Pemetaan Kemiskinan dan Otonomi Daerah di Provinsi Bali dengan Multidimensional Scaling. Kemiskinan dan otonami daerah sudah menjadi isu yang hangat di Indonesia. Masalah kemiskinan telah menjadi salah satu fokus baik dalam MDGs dan SDGs. Otonomi daerah juga sudah menjadi perhatian besar dalam perkembangan pengelolaan pemerintah di Indonesia, mengingat perkembangan otonomi daerah menemui banyak sekali tantangan seperti korupsi dengan indikator berupa kepala daerah yang terkena masalah korupsi. Untuk itu hal ini penting untuk dipetakan agar memberikan gambaran visual yang baik mengenai otonomi daerah dan kemiskinan. Penelitian ini dilakukan di Provinsi Bali tahun 2018 dengan menggunakan data time series. Penelitian ini menggunakan multidimensional scaling untuk memetakan hubungan antara objek yang memiliki kesamaan. Penemuan dalam penelitian ini bahwa otonomi daerah tidak menghasilkan hubungan yang sama dengan kemiskinan di setiap daerah di Provinsi Bali. Untuk daerah mandiri kemiskinan rendah seperti Kabupaten Badung dan Kota Denpasar menunjukkan bahwa otonomi daerah dengan tingkat kemandirian keuangan yang tinggi dapat menghasilkan jumlah penduduk miskin yang rendah dibandingkan daerah lain di Provinsi Bali. Terdapat juga penemuan bahwa terdapat daerah tidak mandiri kemiskinan rendah seperti Kabupaten Klungkung, Bangli, dan Jembarana. Kemampuan keuangan daerah tinggi bukan acuan dalam menghasilkan kemiskinan yang rendah di suatu daerah.
\end{abstract}

Kata kunci: Kemiskinan; Otonomi Daerah; MDS. 


\section{PENDAHULUAN}

Kemiskinan telah menjadi salah satu fokus dalam MDGs dan SDGs. Kemiskinan tidak dianggap sebagai masalah dalam dimensi ekonomi, namun melainkan telah meluas hingga dimensi sosial, kesehatan, pendidikan, dan politik (Budhi, 2013). Kemiskinan adalah sebuah keadaan yang serba kekuangan sehingga tidak mampu meninkmati kesehatan, pendidikan, makanan yang layak (Seran, 2017). Tanpa kemiskinan (No Poverty) adalah tujuan besar pertama dalam SDGs yang sekaigus menjadi kesepakatan dan upaya bersama seluruh negara untuk mengakhiri segala bentuk kemiskinan dimanapun (Ramadhani \& Munandar, 2019). Banyak negara berusaha memperbaiki situasi tersebut dengan berbagai pendekatan. Salah satu pendekatan yang digunakan adalah mengubah sistem pengelolan fiskal dari yang sentralisasi fiskal menjadi desentralisasi fiskal. Desentralisasi fiskal dipercaya dapat menyelesaikan masalah ekonomi, kemiskinan, dan lingkungan. Desentralisasi fiskal adalah devolusi yang dilakukan pemerintah pusat kepada pemerintah lokal atau daerah (negara bagian, kabupaten, kota) sebagai fungsi spesifik dengan kewenangan administratif dan penerimaan pajak atau fiskal untuk bekerja sesuai dengan fungsinya (Kee, 2004). Pada saat barang publik yang dikonsumsi ditentukan berdasarkan secara geografi oleh seluruh populasi dan biaya untuk menyediakan setiap output dari barang publik di setiap wilayah hukum sama untuk setiap pemerintah pusat dan lokal untuk menyediakan barang publik, maka penyediaan barang publik akan lebih efesien jika pemerintah lokal menyediakan output pada setiap level pada posisi paretoeffecient dibandingkan pemerintah pusat (Oates, 2006). Desentralisasi akan meningkatkan efesiensi dan mengurangi diparitas regional karena dengan mengimplementasikan sistem pemerintah desentralisasi maka pemerintah regional akan meningkatkan usaha mereka dalam meningkatkan jasa publik (Suharjo et al., 2009). Berdasarkan teori yang dijelaskan diatas maka, desentralisasi fiskal dianggap dapat menyebabkan kinerja pemerintah lokal dapat bekerja lebih efesien dibandingkan pemerintah pusat pada level output pareto tertentu.

Desentralisasi fiskal dipercaya dapat menurunkan tingkat kemiskinan, namun masih terdapat perdebatan karena terdapat berbagai temuan atas hubungan antara desentralisasi fiskal 
dan tingkat kemiskinan. Nursini \& Tawakkal (2019) melakukan penelitian di Indonesia dengan menggunakan model regresi data panel di 33 provinsi antara tahun 2010-2016 menemukan bahwa pendapatan pemerintah dan transfer antar pemerintah secara siginifikan menurunkan kemiskinan, dan pengeluaran pemerintah tidak berdampak terhadap penurunan kemiskinan, ini karena peningkatan pendapatan dan transfer akan menyebabkan pemerintah memiliki fiskal yang cukup untuk mendanai program pengentasan kemiskinan. Kusumaningrum (2013) menemukan hal yang sedikit berbeda mengenai hubungan desentralisasi fiskal dengan kemiskinan di Indonesia, ditemukan bahwa desentralisasi fiskal dapat menurunkan kemiskinan dengan meningkatkan pengeluaran dibidang kesehatan dan pendidikan hanya terjadi di Jawa Timur, Kalimantan Barat, dan Sulawesi Utara, sehingga dapat dikatakan bahwa hubungan ini terjadi pada kasus-kasus tertentu saja. Bjornestad (2009) menjelaskan pengalaman vietnam mengenai hubungan antara desentralisasi fiskal dengan pengentasan kemiskinan, ia menyatakan bahwa hubungan antara desentralisasi fiskal dengan pengentasan kemiskinan adalah positif, namun perlu dicatat bahwa peningkatan transfer fiskal terhadap pengeluaran untuk kemiskinan tidak akan berarti hal ini akan dibelanjakan secara efesien. Agyemang-Duah et al (2018) melakukan studi literatur dan menghasilkan kesimpulan bahwa desentralisasi fiskal akan menurunkan tingkat kemiskinan apabila desentralisasi fiskal mampu meningkatkan akumulasi kapital dari penduduk miskin sehingga mereka bisa ikut terlibat dalam berbagai strategi untuk mendapatkan pekerjaan.

Braun \& Ulrike (2000) Desentralisasi fiskal tidak secara otomatis meningkatkan pengeluaran yang bersifat pro poor, walaupun pengeluaran pada jasa sosial meningkat lebih tinggi namun tidak akan menyebabkan peningkatan jasa untu orang miskin. Ini berarti desentralisasi fiskal tidak selalu akan menghasilkan program yang bersifat pro poor atau program pengentasan kemiskinan. Bird \& Edgard (1999) menjelaskan hubungan antara desentraliasi fiskal dengan penurunan kemiskinan sangat tergantung pada target investasi publik yang menurunkan kemiskinan oleh pemerintah lokal, pemerintah lokal membuat kebijakan kemiskinan dengan menggunakan transfer pendapatan dalam bentuk yang atau yang lain kepada orang miskin, 
pemerintah lokal juga harus meningkatkan kebijakan untuk meningkatkan produktifitas dari orang miskin dengan formasi dan meningkatkan kualitas sumber daya manusia, kesehatan dan meningkatkan akses ke pasar dan sumber daya produktif.

Sepulveda \& Vazquez (2011) melakukan penelitian dengan menggunakan data panel internasional menemukan bahwa desentraliasi fiskal akan menyebabkan peningkatan kemisikinan dan jika secara umum budget pemerintah berkisar pada 20 persen dari PDB atau apabila lebih tinggi akan menyebabkan efek yang kuat dari desentralisasi fiskal dalam meningkatkan distribusi pendapatan. Lebih lanjut desentralisasi fiskal dapat menyebabkan upaya meningkatkan pajak sehingga menyebabkan migrasi yang cenderung menolak peningkatan pajak, migrasi akan berakhir sampai rate tax antar daerah adalah sama. Agegnehu \& Dibut (2016) menemukan hal serupa yakni ethophia tidak terbantu saat desentralisasi diterapkan di negara tersebut karena beberapa faktor penghambat antara lain pertumbuhan penduduk yang mengkawatirkan, kekurangan sumber daya keuangan dan skill menggunakan teknologi, kekurangan budaya transparan dan budaya akuntabilitas yang baik, masalah korupsi. Samputra \& Munandar (2019) menjelaskan hal yang sama bahwa korupsi membawa efek tidak baik terhadap kemiskinan, karena peningkatan korupsi menyebabkan kenaikan tingkat kemiskinan.

Desentralisasi fiskal sudah dilaksanakan semenjak era reformasi di Indonesia. Konsekuensi dari kebijakan tersebut adalah memberikan pengelolaan keuangan kepada pemerintah daerah (Kusuma, 2016). Desentralisasi fiskal yang baik harus dibarengi oleh kemampuan pemerintah daerah untuk mengelola dan menghasilkan pendapatan asli daerahuntukmembiayaipengeluaran pemerintah dalam rangka penyediaan barang publik secara mandiri. Kemandirian keuangan daerah ditujukan oleh besar kecilnya pendapatan asli daerah (PAD) dibandingkan dengan pendapatan daerah yang berasal dari sumber lain, misalnya bantuan pemerintah pusat ataupun pinjaman (Supriyadi et al., 2013). Untuk mengukur kemandirian keuangan daerah dapat digunakan pendekatan dari derajat desentralisasi fiskal (DDF). Pengukuran derajat desentralisasi fiskal menggunakan kesetaran persamaan dengan membagi pendapatan asli daerah dengan total pendapatan daerah (Sumardjoko, 2019). 
Desentralisasi fiskal berkembang dan direalisasikan oleh pemerintah daerah dengan bebagai masalah yang dihadapi. Kemiskinan merupakan salah satu masalah yang telah dihadapioleh seluruh pemerintah daerah sebelum sampai sesudah diterapkannya desentralisasi fiskal. Permasalahan ini merupakan masalah yang pelik, sehingga dibutuhkan kemampuan fiskal dan kebijakan yang tepat untuk setiap daerah agar mampu menyelesaikan masalah ini. Terdapat berbagai temuan yang menjelaskan hubungan antara kemampuan fiskal pemerintah daerah dengan tingkat kemiskinan di Indonesia.

Terdapat berbagai temuan empiris yang menjelaskan hubungan antara desentralisasi fiskal dengan kemiskinan diberbagai negara dan Indonesia. Namun dari seluruh penelitian tersebut belum ada penelitian yang melakukan pemetaan antara desentralisasi fiskal atau otonomi daerah dengan kemiskinan di Indonesia. Untuk itu penelitian ini akan melakukan pemetaan kemampuan fiskal pemerintah daerah dengan kemiskinan di seluruh kabupaten/ kota Provinsi Bali. Ini penting dilakukan untuk membagi dan mengelompokkan masing-masing daerah kedalam 4 kategori.

\section{METODE PENELITIAN}

Penelitian ini dilakukan tahun 2020 di Provinsi Bali. Penelitian ini menggunakan data cross section dari pendapatan asli daerah (PAD), total pendapatan daerah, dan jumlah penduduk miskin seluruh kabupaten/kota di Provinsi Bali Tahun 2018. Penelitian memetakan kondisi otonomi daerah dengan kemiskinan di Provinsi Bali. Penelitian ini menggunakan derajat desentralisasi fiskal (DDF) menggambarkan otonomi daerah dan jumlah penduduk miskin untuk menggambarkan kondisi kemiskinan di setiap kabupaten dan kota di Provinsi Bali. Derajat Desentralisasi Fiskal (DDF) rasio antara Pendapatan Asli Daerah (PAD) dengan Total Pendapatan Daerah (TPD) selama kurun waktu tahun 2018. Data PAD, total pendapatan daerah, jumlah penduduk miskin bersumber dari Badan Statistik Provinsi, dengan menggunakan sumber buku kabupaten/ kota dalam angka tahun 2019. Penelitian menggunakan multidimensional scalling (MDS) untuk memetakan hubungan antara otnomi daerah dengan kemiskinan di Provinsi Bali selama kurun waktu tahun 2018.

Berdasarkan tipe data, multidimensional scaling dibagi menjadi dua yaitu metrik dan non metrik. Multidimensional scaling metrik adalah 
data jarak yang digunakan dalam penskalaan berdimensi ganda metrik adalah data rasio, dimana penskalaan berdimensi ganda metrik ini digunakan untuk menemukan himpunan titik dalam ruang dimensi masing-masing titik yang mewakili suatu objek sehingga jarak antara titik, dan Multidimensional scaling non-metrik adalah penskalaan berdimensi ganda nonmetrik merupakan data yang bertipe ordinal (Walundungo et al., 2014). Penelitian ini menggunakan MDS metrik karena data bersifat rasio. Tujuan utama dari MDS adalah memetakan objek dalam suatu bidang multidimensi sehingga posisi relatif objek dalam bidang tersebut dapat menggambarkan tingkat kedekatan antar objek yang sebenarnya, dimana MDS memberikan gambaran data yang mudah dipahami dan informatif karena hasil MDS berupa gambaran visual (Sutanto, 2007). Pada proses pemetaan otonomi daerah dengan kemiskinan di seluruh Kabupaten dan Kota di Provinsi bali, MDS layak digunakan karena dapat memberikan gambaran informatif mengenai situasi otonomi daerah dengan kemiskinan yang terjadi pada tahun 2018. Melalalui gambaran MDS, maka akan didapatkan kelompok-kelompok objek yang memiliki karakteristik atau jenis yang sama.
MDS akan menghasilkan posisi spasial atau posisi kordinat peta yang telah dideskripsikan sesuai kesamaan dan preferensi ke objek yang lainnya dengan melihat dimensi pada objek tersebut (Martha, 2014).Nilai Stress merupakan kriteria untuk menilai suatu konfigurasi dari objek yang sudah masuk kategori baik atau belum (Martha, 2019). Nilai stress merupakan sebuah gambaran mengenai validitas sebuah kordinat, dimana apakah kordinat yang ditunjukkan mempresentasikan posisi objek sebenarnya. semakin kecil nilai stress yang didapatkan maka semakin baik model MDS, untuk mendapatkan nilai streess maka digunakan persamaan sebagai berikut (Sutanto, 2007).

$$
\text { Stress }=\frac{\sum_{i=j}^{n}\left(d_{i j}-\widehat{d_{l j}}\right)^{2}}{\sum_{i=j}^{n} d_{i j}^{2}}
$$

Dimana, dij adalah jarak antara stimuli i dan j dan dihitung dari kordinat stimulus dalam bidang turunan dan iterasi tertentu dan dij adalah dispariti yaitu transformasi monoton data dibuat semirip mungkin dengan jarak untuk setiap langkah. Kriteria yang kedua adalah kriteria $R$-Square. Nilai $\mathrm{R}^{2}$ merupakan nilai yang menunjukkan bahwa ketepatan dalam mewakili dan menjelaskan data yang diinput (Nafisah \& Setiawan, 2019). R-square 
dalam MDS juga mengindikasikan proporsi varians data yang dapat dijelaskan oleh MDS, semakin besar nilainya maka semakin baik juga modal yang kita peroleh (Sutanto, 2007) Untuk mendapatkan nilai $\mathrm{R}^{2}$ dapat digunakan persamaan berikut ini.

$$
R^{2}=1-\frac{\sum_{i, j}^{n}\left(d_{i j}-\hat{d}_{i j}\right)^{2}}{\sum_{i, j}^{n}\left(d_{i j}-\bar{d}\right)^{2}}
$$

\section{HASIL DAN PEMBAHASAN}

Proses pemetaan dengan menggunakan multidimensional scaling melewati beberapa tahapan dan wajib memenuhi beberapa kriteria seperti nilai stress dan nilai R-square. Nilai stress menunjukkan mengenai validitas sebuah kordinat dan konfigurasi sebuah objek. Nilai R-square menujukkan. Pada penelitian ini diketahui bahwa nilai stress pada model ini adalah 0,28 atau sebesar 28 persen. Nilai stress realtif kecil sehingga model multidimensional scalling dapat digunakan untuk menjelaskan pemetaan objek antara kemiskinan dan otonomi daerah pada penelitian ini. Selanjutnya untuk nilai R-Square sebesar 0.91 atau sebesar 91 persen memiliki arti bahwa sebesar 91 persen model ini dapat menjelaskan pemetaan untuk mengelompokkan masing-masing kabupaten dan kota pada kelompok yang memiliki kemiripan yang sama. Model MDS berikut ini relatif baik karena mampu menjelaskan variasi yang terjadi dari objek yang digambarkan dengan baik, sisanya dijelaskan oleh variabel lain di luar model. Berikut nilai stress dan R-Square disajikan pada Tabel 1.

Tabel 1. Nilai Stress dan RSQ

For Matrix

\begin{tabular}{ll|l}
\hline Stress $=0,2862$ & RSQ $=0,9112$ \\
\hline
\end{tabular}

Sumber: Data Diolah (2020)

Setelah diketahui nilai stress dan $R$-Square, maka dilakukan penghitungan jarak antara dua dimensi. Pada Tabel 2 diketahui jarak untuk mengukur antara satu objek dengan objek lain pada dua dimensi. Dimensi satu menggambarkan kondisi kemiskinan di masingmasing kabupaten dan kota di Provinsi Bali tahun 2018. Dimensi dua menggambarkan kondisi otonomi daerah di masing-masing kabupaten dan kota di Provinsi Bali tahun 2018. Nilai jarak antar objek disajikan pada Tabel 2 diatas. Setelah nilai antara jarak diketahui maka selanjutnya dapat dipetakan kondisi kemiskinan dan otonomi daerah di seluruh kabupaten dan kota di Provinsi Bali Tahun 2018. Pada Gambar 1 menjelaskan kondisi peta hubungan antara 
Tabel 2.

Jarak Kordinat Untuk Dua Dimensi

\begin{tabular}{cccc}
\hline Number & Nama & 1 (Kemiskinan) & 2 (Otonomi Daerah) \\
\hline \hline 1 & Jembrana & $-0,0249$ & $-0,5645$ \\
2 & Tabanana & 0,3261 & $-0,0392$ \\
3 & Badung & $-2,1175$ & 1,9768 \\
4 & Gianyar & 0,6100 & 0,4288 \\
5 & Klungkung & $-0,8160$ & $-0,3924$ \\
6 & Bangli & $-0,6327$ & $-0,785$ \\
7 & Karangasem & 0.8700 & $-0,5058$ \\
8 & Buleleng & 2,3512 & $-0,6105$ \\
9 & Denpasar & $-0,0162$ & 0,4918 \\
\hline
\end{tabular}

Sumber: Data Diolah (2020)

desentralisasi fiskal dengan kemiskinan di kemiskinan yang rendah. Kuardran dua seluruh kabupaten/kota di Provinsi Bali Tahun menggambarkan daerah yang memiliki kondisi 2018. Pada Gambar 1 disajikan kondisi bahwa derajat desentralisasi fiskal yang rendah dan empat kuardran. Kuardran pertama merupakan memiliki kemiskinan yang rendah. Kuardran kuadran yang menggambarkan kondisi tiga merupakan menggambarkan daerah desentralisasi fiskal yang baik karena memiliki yang memiliki daerah yang memiliki derajat derajat desentralisasi fiskal yang tinggi dan desentralisasi fiskal yang tinggi namun memiliki

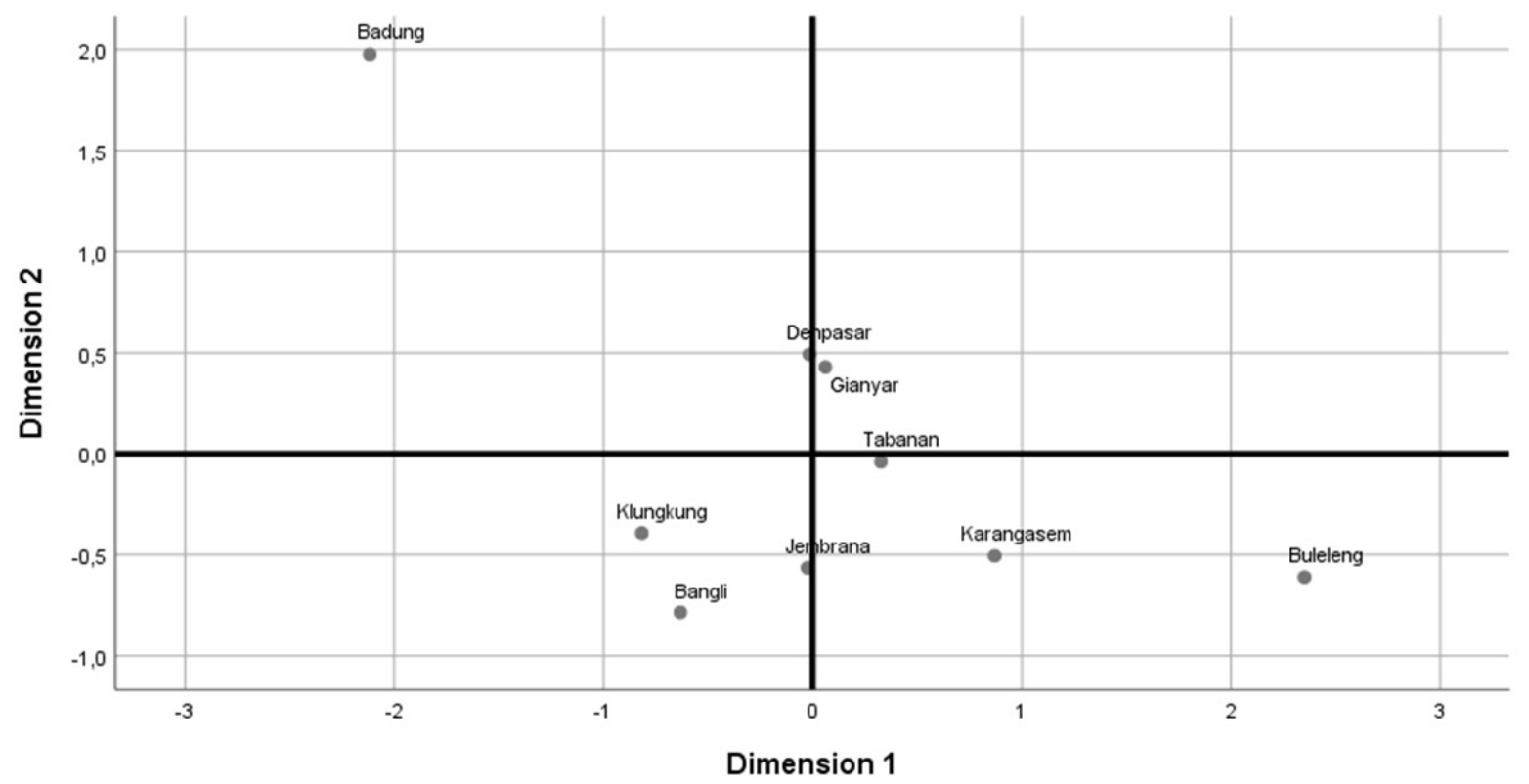

Gambar 1.

Hasil Pemetaan DDF dan Jumlah Penduduk Miskin Tahun 2018 
kemiskinan yang tinggi. Kuardran empat sesuai dengan temuan yang ditemukan oleh menggambarkan daerah yang memiliki daerah Nursini \& Tawakkal (2019) yang menyatakan yang memiliki derajat desentralisasi fiskal yang bahwa dengan sumber pendapatan yang tinggi sangat rendah dan memiliki kemiskinan yang dapat menurunkan kemiskinan. Kabupaten tinggi. Untuk memudahkan pengelompokan Gianyar masuk kedalam kuardran 2, ini berarti maka masing-masing kuardaran akan diberikan Kabupaten ini memiliki derajat desentralisasi nama pengkategorian kelompok, yaitu Kuardran fiskal yang baik atau secara keuangan telah 1 adalah mandiri kemiskinan rendah dan mandiri namun belum tingkat kemiskinan kuardaran 2 adalah mandiri kemiskinan tinggi; masih tinggi. Hal ini dapat terjadi seperti yang Kuardran 3 adalah tidak mandiri kemiskinan ditemukan oleh Bjornestad (2009); Agyemangrendah; Kuardran 4 adalah tidak mandiri Duah etal., (2018); Braun \&Ulrike(2000) bahwa kemiskinan tinggi. Mandiri digunakan sebagai desentralisasi belum tentu akan meningkatkan nama kategori karena otonomi daerah menuntuk kemandirian dari masing-masing daerah untuk menghasilkan pendapatan dalam membiayai pelaksanaan otonomi daerah dimasing-masing kabupaten dan kota.

Kabupaten Badung dan Kota Denpasar merupakan kabupaten yang masuk kedalam kuadran 1. Ini artinya kabupaten dan kota ini memiliki derajat desentralisasi yang tinggi dan jumlah penduduk miskin yang rendah. Ini artinya kondisi keuangan Kabupaten Badung dan Kota Denpasar sangat baik dan relatif mandiri dibandingkan yang lain dan memiliki kondisi kemiskinan yang relatif baik dibandingkan daerah yang lain di Provinsi Bali. Kondisi ini pengeluaran pemerintah yang bersifat pro poor, pengeluaran ini merupakan pengeluaran yang dapat meningkatkan akumulasi modal dari penduduk miskin dan pengeluaran program kemiskinan yang efesien.

Kabupaten Tabanan, Karangasem, dan Buleleng masuk kedalam kuardaran ke 4. Ini berarti kabupaten ini masuk dalam kondisi keuangan yang tidak mandiri dan memiliki kondisi kemiskinan yang tinggi. Ini berarti, desentralisasi fiskal dapat meningkatkan kemiskinan pada daerah ini. Hal ini dapat terjadi karena kekurangan pendapatan untuk membiayai program kemiskinan, sejalan dengan yang ditemukan oleh Agegnehu \& Dibut 
(2016). Kabupaten Klungkung, Jembarana tinggi. Untuk Kabupaten Klungkung, Bangli, dan Bangli merupakan kabupaten yang masuk Jembrane menjadi satu kelompok karena kedalam kuardaran tiga, ini artinya bahwa memiliki kemiripan yang sama dan masuk kabupaten ini memiliki derajat desentralisasi ke dalam daerah tidak mandiri kemiskinan yang rendah namun memiliki penduduk miskin yang rendah juga. Ini berarti kondisi keuangan daerah belum menjadi sebuah acuan penting dalam menurunkan tingkat kemiskinan di kabupaten Klungkung, Jembrana, dan Bangli. Pada kasus kabupaten/kota di Provinsi Bali, ditemukan bahwa desentralisasi fiskal dapat sukses di sebuah kabupaten dengan tingkat kemandirian yang tinggi, namun belum tentu sukses dikabupaten yang lain dengan tingkat kemandirian yang tinggi dan terdapat anomali bahwa daerah tidak mandiri dapat memiliki kemiskinan yang rendah seperti Klungkung, Jembrana dan Bangli. Ini diperkuat oleh temuan Kusumaningrum 92013) bahwa kesuksesan desentralisasi fiskal untuk menurunkan tingkat kemiskinan tidak terjadi disemua daerah dan hanya terjadi dibeberapa daerah tertentu saja. Untuk Kabupaten Badung dan Kota Denpasar pada tahun 2018 diketahui bahwa masuk menjadi daerah yang mandiri kemiskinan rendah.

Untuk Kabupaten Gianyar pada tahun 2018 masuk dalam daerah mandiri kemiskinan rendah. Untuk Kabupaten Karangasem dan Buleleng masuk menjadi satu kelompok yang sama yakni masuk menjad daerah tidak mandiri kemiskinan tinggi. Kemiskinan dan otonomi daerah bukan isu yang mudah, karena hal ini masih membutuhkan banyak pendekatan. Otonomi antara satu daerah dan daerah lain tidak menggambarkan kondisi yang sama atas kemiskinan yang terjadi. Perbaikan terus dilakukan untuk memberikan dampak yang positif dari otonomi daerah terjadap kemiskinan. Otonomi yang dibarengi oleh masalah korupsi juga akan memberikan dampak yang tidak terhadap penanganan kemiskinan disuatu daerah, karena korupsi dapat meningkatkan kemiskinan, hal ini seperti yang ditemukan oleh Samputra \& Munandar (2019). Kondisi perkembangan otonomi daerah memerlukan kajian yang lebih dalam lagi, karena terdapat kasus kepala daerah yang terkena masalah korupsi dan masuk penjara akibat kasus korupsi. Ini merupakan tantangan yang besar terhadap otonomi daerah, mengingat pengelolaan daerah untuk 
memberikan pengaruh terhadap perekonomian dan kemiskinan ada di tangan pimpinan daerah. Pengelompokan yang dihasilan dalam model ini dapat digunakan sebagai acuan untuk pemerintah dalam mengambil kebijakan. Untuk Kabupaten yang masuk kategori daerah mandiri kemiskinan rendah, maka stimulus fiskal dan reward dalam bentuk fiskal kepada daerah tersebut dapat diberikan untuk meningkatkan kinerja daerah tersebu untuk menuntaskan masalah kemiskinan yang terjadi. Untuk daerah yang masuk sebagai daerah mandiri kemiskinan tinggi perlu diberikan pendekatan non-fiskal untuk menyelesaikan masalah ini, karena ada peluang walaupun memiliki kemampuan keuangan yang tinggi dan masuk dalam kategori mandiri bisa saja program yang dihasilkan tidak pro poor seperti yang ditemukan oleh Braun \& Ulrike (2000). Untuk itu perlu dikaji kembali mengenai program yang dihasilkan khusus untuk daerah mandiri kemiskinan tinggi. Hal ini penting dikaji dan diawasi, khusunya apakah program pemerintah sudah pro poor apa belum. Pendataan dan evaluasi program penting dilakukan oleh pemerintah pusat untuk mengawasi kinerja daerah. Apabila sudah memiliki data dan hasil evaluasi, maka pemerintah akan mengetahui pemerintah daerah mana saja yang tidak menghasilkan program pro poor dan daerah yang menghasilkan program pro poor. Setelah data dan evaluasi dilakukan, perlu juga ada sistem punishment bagi daerah yang tidak mampu menghasilkan program yang bersifat pro poor dengan disinsentif fiskal misalnya seperti melakukan pemotongan DAU dan DAK untuk daerah yang gagal menghasilkan pro poor.

Terdapat daerah yang masuk dalam ketegori tidak mandiri kemiskinan tinggi, kasus seperti ini tentu ini dapat terjadi seperti yang temuan yang dijelaskan oleh Agegnehu \& Dibut (2016) karena kekurangan pendapatan tidak mampu untuk membiayai program. Tapi hal ini perlu dikaji lebih dalam lagi, mengingat antara pemerintah daerah dan pusat memiliki program kemiskinan yang berbeda. Pemerintah pusat pada saat yang sama menghasilkan program kemiskinan dan pemerintah daerah juga menghasilkan program kemiskinan. Jumlah program kemiskinan yang berbeda antara pemerintah pusat dan daerah menimbulkan pertanyaan mengenai program yang memberikan dampak terhadap kemiskinan. Sehingga untuk daerah tidak 
mandiri kemiskinan tinggi perlu perhatian yang lebih baik dalam perencaan pemberian bantuan tambahan fiskal seperti DAU dan DAK. Daerah tidak mandiri kemiskinan tinggi memerlukan perhatian khusus dari pemerintah, perhatian bukan hanya kebijakan yang bersifat mendukung kemampuan keuanganya, namun juga hal lain seperti bagaimana menghasilkan program yang baik dan memberikan dampak yang maksimal terhadap kemiskinan.

Daerah tidak mandiri kemiskinan rendah merupakan suatu gambaran bahwa kemiskinan yang rendah tidak hanya mampu dihasilkan oleh pemerintah daerah yang memiliki kemampuan keuangan yang baik, namun juga mampu dihasilkan oleh pemerintah yang tidak mandiri. Hal ini perlu dikaji lebih lanjut, mengingat daerah yang tidak mandiri tentu tidak memiliki kemampuan fiskal yang baik untuk membiayai program secara leluasa seperti pemerintah yang memiliki kemampuan fiskal yang besar. Banyak yang perlu dikaji dalam hal ini, apakah pada daerah tidak mandiri kemiskinan yang rendah dihasilkan dari program yang efektif dan efesien serta bersifat pro poor atau ada hal lain yang menyebabkan hal ini terjadi seperti pertumbuhan penduduk, perpindahan penduduk, mengingat kemiskinan bukan hanya masalah ekonomi saja, namun masalah multidimensi yang terkait dengan berbagai hal yang terjadi didaerah tersebut. Sehingga dari gambaran ini, kemiskinan tidak bisa hanya diselesaikan dengan hanya bermodal kemampuan keuangan yang tinggi. Untuk daerah tidak mandiri kemiskinan rendah perlu dilakukan kebijakan reward bagi daerah seperti ini, misalnya memberikan tambahan DAU atau DAK kepada daerah tidak mandiri kemiskinan rendah. Reward dapat diberikan untuk memacu daerah lain agar memiliki kinerja yang baik dalam menangani masalah kemiskinan. Pengelompokan daerah pada masing-masing kelompok daerah memberikan arah yang memudahkan pemerintah pusat untuk membuat sebuah kebijakan, karena kebijakan untuk setiap kelompok dapat dibedaan dan masalah yang terjadi dapat dipetakan dengan baik. Pemetaan ini telah banyak memberikan gambaran kepada kita bahwa banyak hal yang dapat dijelaskan melalui MDS ini. Walaupun demikian, masih banyak sekali kekurangan yang dimiliki dalam penelitian ini. Penelitian ini masih memiliki kelemahan berupa belum mengaktegorikan besaran dampak dari otonomi 
daerah berdasarkan program yang dilakukan, dengan temuan Nursini \& Tawakkal (2019) sehingga untuk itu perlu dilakukan lebih lanjut bahwa otonomi daerah dapat menurunkan untuk melakukan penelitian mengenai dampak tingkat kemiskinan. Hal ini dapat terjadi karena otnomi daerah terhadap kemiskinandi Indonesia. dengan sumber keuangan yang baik, maka Kategori yang dihasilkan dalam penelitian ini daerah dapat membiayai dan membuat program dapat dijadikan acuan untuk mengelompokkan yang sesuai dengan karakteristik kemiskinan yang sama dan menguji dampak otonomi pada daerah tersebut. Apabila kapasitas sehingga menghasilkan besar nilai dampak yang keuangan daerahnya kurang, maka tentu tidak mampu dihasilkan oleh otonomi daerah untuk mungkin membuat program yang bersifat pro mengurangi tingkat kemiskinan disuatu daerah. poor. Namun, terdapat anomali dimana terdapat

\section{SIMPULAN DAN SARAN}

Kemiskinan dan otonomi daerah merupakan isu yang menjadi sangat penting dalam meningkatkan kualitas kehidupan dan ekonomi di Indonesia. Sudah terdapat banyak penelitian yang menjelaskan hubungan antara otonomi daerah atau desentralisai fiskal dengan kemiskinan. Terdapat berbagai temuan mengenai dampak otnomi daerah terhadap kemiskinan. Pada penelitian ini ditemukan fakta yang berbeda antara satu kelompok daerah dengan kelompok daerah lain. Berdasarkan pemetaan, terdapat daerah yang memiliki kemandirian yang tinggi dan jumlah penduduk miskin yang rendah seperti badung yang masuk sebagai daerah mandiri kemiskinan rendah. Ini sesuai daerah tidak mandiri kemiskinan rendah seperti Kabupaten Klungkung, Bangli, Jembrana. Hal baru yang terjadi pada daerah tidak mandiri kemiskinan rendah, bisa terjadi karena banyak faktor misalnya seperti penanganan pertumbuhan penduduk dan lain sebagainya. Ini menggambarkan belum tentu daerah yang tidak mandiri harus memiliki kondisi kemiskinan yang buruk. Jadi kemampuan keuangan bukan suatu hal yang utama dalam menurunkan tingkat kemiskinan diusatu daerah. Hal ini sangat mungkin terjadi karena banyak yang dapat mempengaruhi tingkat kemiskinan. Perlu dilakukan kajian kembali menganai otonomi daerah dan kemiskinan di Provinsi Bali khusunya dan di Indonesia secara umum. 


\section{REFERENSI}

Agegnehu, A. \& Worku D. 2016. Does Decentralization Have a Role in Poverty reduction? The Ethiopiam Experience. Journal African Studies and Development. Vol 9 No. 1, pp: 1-6. doi: 10.5897/JASD2016.0421.

Agyemang-Duah et al. 2018. Reducing Poverty Through Fiscal Decentralization in Ghana and Beyond: A Review. Cogent Economics \& Finance. 6(1):1-14. DOI: $10.1080 / 23322039.2018 .1476035$

Bird, R. \& Edgard R. R. 1999. Decentralization and Poverty Alleviation, International Experience and The Case Of The Philippines. Public Administration And Developement. 19, PP: 299-399.

Bjornestad, L. 2009. Fiscal Decentralization, Fiscal Incentive, and Pro-Poor Outcomes: Evidence From Viet Nam. ADB Economics Working Paper Series. No.168.

Braun, J. V. \&Ulrike G. 2000. Does Decentralization Serve the Poor. IMFConference On Fiscal Decentralization 20-21 November. Washitong D.C. Diakses Pada: https://www.imf.org/ external/pubs/ft/seminar/2000/fiscal/ vonbraun.pdf

Budhi, M. K. S. 2013. Analisis Faktor- Faktor yang Berpengaruh Terhadap Pengentasan Kemiskinan di Bali: Analisis FEM Data Panel. Jurnal Ekonomi Kuantitatif Terapan. Vol. 6 No. 1, pp: 1-6.

Kee, J. 2004. Fiscal Decentralization: Theory As Reform. Administration Public, Panama, Washiton DC. Diakses pada Tanggal 1 Juni 2020. Researchgate : https ://www.researchgate.net/ publication/251886012

Kusuma, H. 2016. Desentralisasi Fiskal dan Pertumbuhan Ekonomi di Indonesia. Jurnal Ekonomi Kuantitatif Terapan. Vol. 9 No.1, pp: 1-11. doi.org/10.24843/ JEKT.2016.v09.i01.p01

Kusumaningrum, S. D. 2013. Link Of Fiscal Decentralization To Poverty Reduction: Indonesia Context. Jurnal Economia. Vol.9. No.2, pp: 116-129. https://doi. org/10.21831/economia.v9i2.1803
Martha, S. 2019. Pemetaan Pembangunan Sekolah di Kapuas Hulu Menggunakan Metode Multidimennsional Scaling. Jurnal Matematika dan Pendidikan Matematika. 4(2), 87-93.

Nafisah, S. \& Setiawan, H. T. 2019. Penerapan Analisis Multidimensional Scaling pada Pemetaan Karakteristik Kemiskinan di Provinsi Banten. Jurnal Statistika dan Matematika. 1(2), 46-59.

Nursini, N. \& Tawakkal. 2019. Poverty Alleviation In The Contex Of Fiscal decentralization in Indonesia. Economics And Sociology. 12(1). 270-285. doi:10.14254/2071-789X.2019/12-1/16

Oates, Wallace E. 2006. On The Theory and Practice Of Fical Decentralization. IFIR Working Paper Series. https://www. researchgate.net/publication/5110773

Ramadhani, A. W. \& Adis I. Munandar. 2013. Determinan Kemiskinan Anak di Provinsi DKI Jakarta: Susenas 2017. Jurnal Ekonomi Kuantitatif Terapan. Vol.12 No.2, pp: 111-123. doi. org/10.24843/JEKT.2019.v12.i02.p01

Samputra, L. P. \& Adis I. Munandar. 2019. Korupsi, Indikator Makro Ekonomi, dan IPM terhadap Tingkat Kemiskinan di Indonesia. Jurnal Ekonomi Kuantitatif Terapan. Vol.12 No.1, pp: 35 - 46. doi. org/10.24843/JEKT.2019.v12.i01.p04

Sepulveda, C. F. \& Vazquaes J. M. 2011. The Consequence of Fiscal Decentralization On Poverty and Income Equality. Enviromental and Planning $C$ : Government and Policy. Vol 29, pp: 321-343. doi:10.1068/c1033r.

Seran, S.2017. Hubungan antara Pendidikan, Pengangguran, dan Pertumbuhan Kemiskinan dengan Kemiskinan . Jurnal Ekonomi Kuantitatif Terapan. Vol. 10 No.2, pp: 59-71. doi.org/10.24843/ JEKT.2017.v10.101.p07

Suhardjanto, et all. 2009. The Influence Of Fiscal Decentralization On The Public Expendeture In Indonesia. Jurnal Siasat Bisnis Vol. 13 No. 3 : 233-252.

Sumardjoko, I. 2019. Penguatan Kinerja Keuangan Daerah Wilayah Kepulauan dan Implikasinya terhadap Perubahan Fundamental Ekonomi regional. Jurnal 
Desentralisasi Fiskal, Ekonomi, dan Keuangan Daerah. Vol. V, pp: 1-21.

Supriyadi et al. 2013. Analisis Desentralisasi Fiskal di Kabupaten Bungo. Jurnal PerspektifPembiyaan dan Pembangunan Daerah. Vol. 1 No.2, pp: 1-10.

Sutanto, Y. E. 2007. Skala Multidimensi. Skripsi. Yogyakarta: Fakultas Sains dan Teknologi Universitas Sanata Dharma. 